\title{
HINDSKI FRAZEMI SA SASTAVNICOM ROṬĪ/KRUH I NJIHOVI PRIJEVODNI EKVIVALENTI U HRVATSKOME JEZIKU
}

\author{
Višnja Grabovac* \\ Filozofski fakultet Sveučilišta u Zagrebu
}

\begin{abstract}
Svrha je rada predstaviti hindske frazeme sa sastavnicom iz semantičkoga polja hrane, točnije sa sastavnicom roțī (hrv. kruh) te ponuditi njihove prijevodne ekvivalente u hrvatskome jeziku ilustrirajući ih pritom primjerima njihove uporabe. Prema tipologiji frazeološke ekvivalencije u radu izneseni hindski frazemi bit će podijeljeni u četiri skupine: frazemi potpune, djelomične, samo semantičke i nulte ekvivalencije. U radu će se navesti dvadeset i dva hindska frazema od kojih je sedamnaest izlučeno iz hindskoga frazeološkog rječnika, dok je preostalih pet pronađeno mrežnim pretraživanjem i dodatno potvrđeno usmenom komunikacijom s izvornim govornikom hindskoga jezika. U radu će se također pokazati da relativno mali broj frazema nulte ekvivalencije proizlazi iz činjenice da je uloga roṭi u indijskoj kulturi usporediva s ulogom kruha u hrvatskoj, odnosno da su hindski i hrvatski frazemi motivirani usporedivom frazemskom pozadinskom slikom. Pojedinim će se primjerima uporabe hindskih frazema pokušati ukazati i na poteškoće koje se mogu javiti pri njihovu prevođenju.
\end{abstract}

Ključne riječi: hindski jezik, hrvatski jezik, frazem, frazeološka ekvivalencija, roțī, kruh.

\section{UVOD}

Prevođenje je frazema vrlo često iznimno zahtjevno čak i kada je riječ o frazemu na jeziku koji je ciljnomu jeziku blizak i strukturom i kulturološkom pozadinom. Izazovi su za prevoditelja, naravno, još i veći ako je izvorni jezik strukturno različit te uz to odražava kulturu bitno različitu od kulture ciljnoga jezika. Unatoč tomu što ne postoje univerzalne metode ili strategije za prevođenje frazema, cilj bi prevoditelja trebao biti, kako ističe Forko (2009: 95), prevesti frazem frazemom. ${ }^{1} \mathrm{U}$ idealnome će slučaju frazeološki ekvivalent u ciljnome jeziku odgovarati frazemu u izvornome jeziku i na planu sadržaja i na planu izraza, međutim valja istaknuti da je „frazeologiju jednoga jezika,

\footnotetext{
*vgrabova@ffzg.hr

1 Isto tvrdi i Vidović Bolt kada piše: „Zadaća je svakoga prevoditelja adekvatno zamijeniti frazem polaznoga jezika frazemom u ciljnom jeziku, dakle, pronaći ekvivalentni frazem, a ako takav ne postoji, prevoditelj se treba odlučiti za neki drugi adekvatni translatološki postupak" (Vidović Bolt, 2019: 345).
} 
osobito njezin nacionalni dio, vrlo teško, ponekad i nemoguće, uspješno prevoditi na druge jezike“ (Menac, Fink-Arsovski i Venturin, 2003: 7). ${ }^{2}$

U ovome će se radu predstaviti frazemi u hindskome jeziku ${ }^{3}$ koji sadrže sastavnicu iz semantičkoga polja hrane, točnije sastavnicu roțī (hrv. kruh), te će se ponuditi njihovi prijevodni ekvivalenti u hrvatskome jeziku. Prema tipologiji frazeološke ekvivalencije, $u$ radu izneseni hindski frazemi bit će podijeljeni u četiri skupine: frazemi potpune, djelomične, samo semantičke i nulte ekvivalencije, a njihova će uporaba biti ilustrirana i primjerima. $U$ radu će se iznijeti ukupno dvadeset i dva hindska frazema sa sastavnicom roți od kojih je sedamnaest izlučeno iz hindskoga frazeološkoga rječnika, dok ih je pet pronađeno mrežnim pretraživanjem i dodatno potvrđeno usmenom komunikacijom s izvornim govornikom hindskoga jezika.

Budući da do sada u Hrvatskoj nije bilo objavljenih radova koji za svoj predmet imaju frazeme $u$ hindskome jeziku, ovaj je rad zamišljen kao prvi korak u zbližavanju hindske i hrvatske frazeologije. Rad je, između ostaloga, pisan u nadi da će biti koristan studentima indologije Odsjeka za indologiju i dalekoistočne studije Filozofskoga fakulteta u Zagrebu. Naime, nastavnim su planom studija indologije obuhvaćeni kolegiji na kojima se prevode žanrovski raznovrsni hindski tekstovi na hrvatski jezik, ali i ne obratno. Razlog je tomu činjenica da je hindski jezik po broju govornika četvrti po veličini jezik na svijetu, književna mu i novinarsko-publicistička produkcija nadmašuje hrvatsku pa je težište na prevođenju hindskih tekstova na hrvatski jezik, ali ne i obratno, razumljivo.

\section{OPĆENITO O FRAZEMU U HRVATSKOJ I HINDSKOJ FRAZEOLOGIJI}

Osnovna je frazeološka jedinica u hrvatskome jeziku frazem iako se $\mathrm{u}$ postojećoj literaturi susreću i drugi nazivi koji odražavaju svojevrsnu zbrku koja je vladala u početcima razvoja frazeologije u Hrvatskoj. Među njima se mogu susresti stalni izraz, stalni leksički kompleks, idiom, idiomatski izraz, idiomatska fraza, ustaljeni izraz, okamenjena fraza (Kovačević, 2012: 6). U novije su se vrijeme izdvojili nazivi frazem i frazeologizam (Menac, 1994: 161), s tim da se u suvremenoj literaturi najčešće susreće naziv frazem. U Hrvatskome frazeološkom rječniku frazemi su definirani na sljedeći način:

Frazemi su ustaljene sveze riječi koje se upotrebljavaju u gotovu obliku, a ne stvaraju se u tijeku govornog procesa, i kod kojih je barem jedna sastavnica promijenila značenje, tako da značenje frazema ne odgovara zbroju značenja njegovih sastavnica. (Menac, Fink-Arsovski i Venturin, 2003: 6)

\footnotetext{
${ }^{2}$ O poteškoćama i postupcima za prevođenje frazema u Vidović Bolt (2019: 350-356), Forko (2009), Pavlović (2015: 88-94), Baker (1992: 63-78).

${ }^{3}$ Hindski jezik pripada indoarijskome izdanku indoiranske grane indoeuropske jezične porodice kojoj pripada i hrvatski jezik kao izdanak baltoslavenske grane. Službeni je jezik Republike Indije od 1950. godine. Piše se pismom devanāgarī.
} 
Drugim riječima, značenje frazema u hrvatskome, ali i u drugim jezicima, ne proizlazi iz značenja njegovih pojedinih sastavnica već u procesu desemantizacije dolazi do promjene značenja cjeline. Veze riječi u frazemu nisu slobodne, odnosno unaprijed su i čvrsto zadane, a zbog čvrste strukture frazema "njihovi se dijelovi obično i ne osjećaju kao riječi sa samostalnim značenjem“" (Menac, 1970: 1).

Desemantizacija može biti potpuna (sve su sastavnice $u$ frazemu semantički preoblikovane) i djelomična (samo je dio sastavnica izgubio svoje primarno leksičko značenje) (Fink-Arsovski, 2002: 7). Značenje se frazema određuje i prema semantičkome talogu ili frazemskoj pozadinskoj slici koju je Fink-Arsovski (1994 u Turk i Opašić, 2008: 19, bilj. 1) definirala kao unutarnju sliku koja motivira frazem.

Matešić (1982: vi) navodi četiri obilježja frazema: reproduciranje, formalno ustrojstvo, idiomatičnost i uklapanje u kontekst, dok Menac (1994: 161, bilj. 1) nadodaje kako se među radovima frazeologa mogu naći i druge određujuće osobine frazema kao što su metaforičnost, neprobojnost, emocionalnost, nacionalni karakter, neprevodivost i dr. Napominje, međutim, kako ih je teško smatrati obveznim.

Frazemi se mogu proučavati iz različitih perspektiva, međutim temeljni su pristupi proučavanju frazema strukturna, sintaktička i semantička analiza:

Semantička se analiza bavi frazeološkim značenjem, načinom njegova formiranja, motiviranošću, porijeklom frazema itd., sintaktička se odnosi na uključivanje frazema u rečenično ustrojstvo, na određivanje njegove funkcije, dok se strukturna bavi čisto formalnom stranom: opsegom frazema, leksičkim sastavom i određivanjem sintaktički glavne (noseće) komponente. (FinkArsovski, 2002: 8)

Po opsegu se frazemi najčešće dijele na tri tipa: fonetska riječ (sastoji se od jedne samostalne i jedne (ili više) nesamostalnih riječi, pri čemu taj tip čini jednu naglasnu cjelinu), skup riječi (sastoji se od najmanje dviju samostalnih riječi s najmanje dvjema naglasnim cjelinama, a dalje se dijeli na zavisni i nezavisni skup riječi), i frazemi sa strukturom rečenice (FinkArsovski, 2002: 8).

U hindskoj se gramatičkoj tradiciji ustalio naziv muhāvarā. Riječ muhāvarā arapskoga je podrijetla, a značenje joj je 'an idiom, a current expression, usage, practise, habit' (McGregor, 1997: 828). Unatoč velikom broju rječnika u kojima se iznose hindski frazemi, frazeologiji hindskoga jezika u Indiji (ali i šire) nije se pristupalo metodološki jasno. Iako se $u$ većini indijskih udžbenika za učenje hindskoga jezika iznose frazemi s njihovim značenjem, oni ipak nisu izneseni sustavno niti im se pristupa iz jasno određene perspektive. Tiwari (1991: 6-7) u uvodu svojega rječnika hindskih frazema ne donosi sasvim jasnu definiciju frazema, ali navodi neka njihova obilježja: značenje im je ustaljeno, imaju preneseno značenje, sastavnice se frazema 
najčešće ne mogu zamijeniti sinonimima ili drugim riječima, uklapaju se u rečenice kao njihov sastavni dio, njihovo je prevođenje često vrlo zahtjevno. Pišući o motiviranosti frazema navodi kako mogu biti motivirani slikovitim usporedbama, tjelesnim funkcijama, prirodnim pojavama, povijesnim događajima i sadržajem književnih djela (Tiwari, 1991: 6). Autor ističe nadalje da se mogu proučavati iz različitih perspektiva te kao primjere polazišnih točaka navodi podrijetlo (jesu li, primjerice, preuzeti iz sanskrta, arapskoga, engleskoga ili nekoga drugog jezika), uporabu (upotrebljavaju li ih žene, sportaši, vojnici, odvjetnici itd.) i sadržaj (odnose li se na društvo, zdravlje, rat itd.) (Tiwari, 1991: 7). Ostatak svoga uvoda posvećuje navođenju primjera takvih izraza u indijskim književnim djelima iz različitih razdoblja, a zaključuje ga listom engleskih frazema koji su ušli u hindski jezik ili koji svoj ekvivalent imaju u hindskome jeziku. R. J. Sarhindī (1940), autor drugoga konzultiranoga rječnika, donosi još manje informacija. Nažalost, zaključke pojedinih indijskih autora do kojih sam uspjela doći mrežnim pretraživanjem ne smatram pouzdanim, pa s obzirom na to da frazemima pristupaju bez jasne metodologije i jedinstvene terminologije nisam ih navela u ovome radu.

\section{ROṬT / KRUH}

Roți je imenica ženskoga roda pod kojom se podrazumijeva plosnata, tanka pogačica od beskvasnoga tijesta i ispečena na tavi bez ulja ili masti. Iako izgledom, sastavom i strukturom tijesta ne nalikuje na kruh (ili pogaču) kakav se uglavnom jede u Hrvatskoj već više na palačinku, predloženi je prijevod ipak kruh budući da se riječ roți, kako će se pokazati dalje u radu, javlja u usporedivim frazemima te da je uloga roți u indijskoj kulturi usporediva s ulogom kruha u hrvatskoj kulturi. Kruh, čiji su primarni sastojci brašno i voda, od najranijih je vremena jedna od najzastupljenijih i najdostupnijih vrsta hrane te se smatra jednim od temelja čovjekove ishrane. Ne čudi stoga brojnost frazema u hrvatskome, ali i drugim jezicima s leksemom kruh koji Hrnjak (2007: 198) smatra „svojevrsnim prototipnim predstavnikom semantičkog polja hrane".

U hrvatskoj je frazeologiji kruh poistovjećen sa životom i shvaćen kao uvjet za preživljavanje o čemu svjedoče i frazemi kao što su, primjerice zaraditil zarađivati za <svoj> kruh 'živjeti od svoga rada, zaraditi/zarađivati za život, biti financijski samostalan' i uzetil uzimati (otetil otimati) kruh iz usta komu 'oduzeti/oduzimati sredstva za život komu, lišiti/ lišavati zarade (posla) koga, baciti/ bacati u bijedu koga' (Opašić, Čunović i Fumić, 2014: 94). I u Indiji se kruh smatra temeljem čovjekove ishrane, a unatoč činjenici da $u$ Indiji postoje različite vrste pogačica čiji su temeljni sastojci brašno i voda, kao što su primjerice ćapāt $\bar{l}, p \bar{u} r \bar{r}, n \bar{a} n$ i parăthāa, u hindskome je jeziku upravo roți, riječima A. Hrnjak (2007), predstavnica semantičkoga polja hrane. The Oxford Hindi-English Dictionary uz natuknice ćapātī, pūrì, nān i parāth ā navodi 
samo njihovo značenje ( $u$ pravilu 'round cake of unleavened flour'), dok uz natuknicu roți, navodi i preneseno značenje 'livelihood' (McGregor, 1997, str. 872). Također, rječnici hindskih frazema kojima sam se služila ne donose frazeme sa sastavnicom pūrí, nān i parăthā, te bilježe samo jedan frazem sa sastavnicom ćapātī, a kojim se opisuje ravan trbuh. Značenje je sintagme rozī roți 'svagdašnja roțti' (hrv. svagdašnji kruh, odnosno život, preživljavanje) što potvrđuje i sljedeći primjer:

$\bar{A} g$ itnì tez thī ki pal bhar me hì gharelu sāmān sahit nakadì đalkar khāk ho gayā. Pị̀it parivār ke sāmne rozī rotī ka sañkat kharāa ho gayā hai. ${ }^{4}$

Vatra je bila toliko snažna da su kuća, kao i novac, za tren izgorjeli i pretvorili se u pepeo. Ugrožen je svagdašnji kruh oštećene obitelji.

Frazemi koji sadrže leksem roți, kako će se pokazati u radu, također svjedoče da je roțī shvaćena kao uvjet za život ili preživljavanje. Da je kruh ispravan prijevod potkrjepljuju i hindski prijevodi novozavjetnih tekstova $u$ kojima se spominje kruh. Tako je, primjerice, ulomak iz Evanđelja po Mateju "Čovjek ne živi samo o kruhu, nego o svakoj riječi, što dolazi iz usta Božjih" (Mt 4:4), preveden na hindski jezik na sljedeći način:

Manusyă keval rotī hī se nahī parantu har ek vaćan se đo parameśvar ke mukh se nikaltā hai jüvit rahegā. ${ }^{5}$

Hindski prijevod molitve Očenaš također sadrži imenicu roțī: hamārī

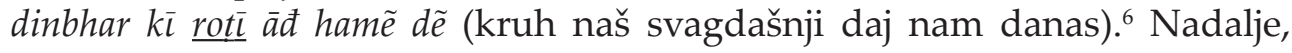
prijevod engl. bread na hindski jezik je dabal roțĭ, dupla/ dvostruka roțī (Verma i Sahai, 2003: 92). Motivacija takvoga prijevoda nije sasvim jasna iako postoji mogućnost da se pod dabal (engl. double) misli na roțī s kvascem koji diže tijesto i čini ga "dvostruko debljim“.

\section{KORPUS I METODA ANALIZE}

U radu se predstavljaju ukupno dvadeset i dva hindska frazema kojima je barem jedna sastavnica roți . Za svaki se hindski frazem, koliko je to bilo moguće, daje njegov doslovan prijevod, a mrežnim se pretraživanjem nastojalo naći i primjer uporabe svakog frazema.

Sedamnaest je hindskih frazema sakupljeno iz hindskoga frazeološkoga rječnika Hind̄̄ Muhāvarā Koś (1991) autora Bholānātha Tivāriaa, a ti su frazemi uvršteni i u drugi konzultirani rječnik Hindī Muhāvarā Koś (1940) autora R. J. Sarhindīa. Riječ je o sljedećim frazemima:

- Roṭi kamāna

\footnotetext{
${ }_{4}$ https://www.naidunia.com/chhattisgarh/janjgir-champa-aagjani-se-ghar-ka-saman-khakh-2944208 (prosinac 2019.).

5 https://www.christiansinindia.in/who-we-are/ (prosinac 2019.).

${ }^{6}$ http://www.marysrosaries.com/Hindi_prayers.html (prosinac 2019.).
} 
- Roṭi ćalāna

- Roṭiyā lagānā

- Roṭiyā lagnā

- Roțiyã tornāā

- Muft kī rotịã tornā

- Roțī pānī ke cakkar mẽ honā

- Roṭiyõ ke lāle parnā

- Roți ko tarasnā

- Dānt kāṭi roțī khānā

- Roṭi par roțī rakhkar khānā

- Roțī kī khāk jhārnā

- Dāl roțī se khuś

- Roṭī pānī mẽ lagnā

- Dānt kātị roțī honā

- Roțī bețì honā

- Dāl rotịi ćalna

Među njima postoje frazemi za koje mrežnim pretraživanjem nije pronađen primjer uporabe što sugerira njihovu zastarjelost u svakodnevnome govoru. Ti su označeni zvjezdicom $\left(^{*}\right)$, a navedeni su $u$ radu jer postoji mogućnost da se čitatelj/prevoditelj s njima susretne pri čitanju/prevođenju starijega teksta na hindskome jeziku. Primjeri njihove uporabe uzeti su iz rječnika i stoga nisu obrojčani (v. poglavlje 5). Potrebno je napomenuti da spomenuti hindski rječnici pridjevne i glagolske tvorbene i leksičke inačice obrađuju pod zasebnim natuknicama. Hindski rječnici slijede model obradbe frazema pod prvom riječi, a koji se može nazvati mehaničkim modelom. ${ }^{7}$ Budući da hindski rječnici obrađuju pridjevne i glagolske inačice frazema pod zasebnim natuknicama, one su tako obrađene i u ovome radu.

U korpus je, uz frazeme koji se nalaze u korištenim rječnicima, uvršteno i pet frazema koji nemaju svoje mjesto u navedenim frazeološkim rječnicima, ali koji se navode na mrežnim stranicama koje donose popis hindskih frazema. To su sljedeći frazemi:

- Rozi roṭi kamāna

- Do đūn ki roțī

- Rozì roțī ke cakkar mẽ honā

- Ek tave kī roṭī, kyā ćhoṭî kyā moțī

- Roṭī pānì.

Ti su frazemi označeni dvjema zvjezdicama $\left.{ }^{* *}\right)$, a njihov je izvor naveden $\mathrm{u}$ bilješci uz frazem. Prisutnost tih frazema u svakodnevnom govoru, kao i zastarjelost frazema označenih s jednom zvjezdicom, potvrđena je i usmenom komunikacijom s dr. sc. Jyoti Śarmom sa Sveučilišta u Delhiju,

$\overline{7}$ V. Hudeček i Mihaljević (1997: 24). 
trenutačno gostujućom lektoricom za hindski jezik na Odsjeku za indologiju i dalekoistočne studije Filozofskoga fakulteta u Zagrebu.

Primjeri uporabe frazema koji su pronađeni mrežnim pretraživanjem označeni su rednim brojem, a njihov se izvor navodi u bilješci uz primjer (v. poglavlje 5). Izvori za primjere uporabe frazema u najvećoj su mjeri novinski članci pronađeni mrežnim pretraživanjem. Drugim riječima, primjeriuporabe frazema tražili su se uglavnom u jeziku tzv. publicističkoga funkcionalnog stila. Glavni razlog tomu leži u činjenici da publicistički funkcionalni stil pokazuje „živost i funkcionalnost“, a obilježje mu je i „težnja ovjerenosti upotrijebljenih jezičnih elemenata" (Hudeček i Mihaljević, 2009: 10). Također, uporaba je frazema u medijima vrlo česta jer „osim obavijesti, oni nose i veliku izražajnost i specifičnost izraza, što privlači pažnju gledatelja ili čitatelja" (Mihaljević i Kovačević, 2006: 6).

Hindskim se jezikom kao materinskim ili drugim jezikom služi oko šest stotina milijuna ljudi pa se, s obzirom na broj govornika, iznimnu dijalektnu raslojenost i geografsku rasprostranjenost, aktualnost i općepoznatost frazema može do određene mjere potvrditi i primjerima njihove uporabe $u$ masovnim medijima kao što je internet. Razlog za predstavljanje frazema koji nisu uvršteni u korištene hindske rječnike kao i predstavljanje u rječnicima nepotvrđenih frazemskih inačica kao zasebnih frazema leži i u činjenici da za sada ne postoji nacionalna leksikografska baza standardnoga hindskoga jezika kao ni nacionalni korpus tekstova na standardnome hindskom jeziku. Stoga se, s obzirom na nemogućnost utvrđivanja koji frazemi pripadaju standardnome jeziku i preciznije potvrde učestalosti pojedinih frazeoloških varijanti, smatralo korisnim pod zasebnim natuknicama predstaviti sve frazeme do kojih se došlo rječničkim i mrežnim pretraživanjem.

Hrvatski frazemi sa sastavnicom kruh prikupljeni su iz Hrvatskoga frazeološkoga rječnika (Menac, Fink-Arsovski i Venturin, 2003) kao i s mrežnih stranica Baze frazema hrvatskoga jezika ${ }^{8}$ i Kolokacijske baze hrvatskoga jezika9. Konzultiran je također i Frazeološki rječnik hrvatskoga ili srpskoga jezika (1982) Josipa Matešića.

S obzirom na svrhu rada - predstaviti frazeme u hindskome jeziku koji sadrže sastavnicu iz semantičkoga polja hrane, točnije sastavnicu roțī (hrv. kruh) te ponuditi njihove prijevodne ekvivalente u hrvatskome jeziku prikupljeni materijal analiziran je metodom kontrastivne analize.

Začetnikom se kontrastivne analize smatra Robert Lado koji je 1957. godine objavio knjigu Linguistics across Cultures: Applied Linguistics for Language Teachers. Pretpostavka koja prožima njegov rad jest da se $u$ doticaju sa stranim jezikom ili tijekom učenja stranoga jezika lakše usvajaju

\footnotetext{
${ }^{8}$ http://frazemi.ihjj.hr/

${ }^{9}$ http://ihjj.hr/kolokacije/
} 
oni elementi jezika koji su slični ili jednaki materinskom jeziku, dok poteškoće predstavljaju oni elementi stranoga jezika koji se razlikuju. Cilj je kontrastivne analize, dakle, utvrditi sličnosti i razlike među jezicima ili njihovim podsustavima (Fisiak, 1980: 1).

Ekvivalencija je središnji pojam kontrastivne analize, a podrazumijeva „odnos dvaju ili više lingvističkih entiteta koji se na temelju postojanja (kompleksa) relevantnih zajedničkih obilježja konceptualiziraju kao istovrijedni u određenom aspektu“ (Čagalj i Svitkova, 2014: 1).

Frazeološka se ekvivalencija najčešće dijeli na potpunu, djelomičnu i nultu ekvivalenciju iako pojedini autori $u$ djelomičnu ekvivalenciju uvrštavaju i samo semantički podudarne frazeme što se, stavi li se naglasak na prijevodni aspekt analize, čini opravdanim (Čagalj i Svitkova, 2014: 4). ${ }^{10}$ U ovome su radu, također, u zasebno potpoglavlje uvršteni samo semantički podudarni frazemi. Potpuna ekvivalencija podrazumijeva isti leksički sastav i gramatička obilježja te istu pozadinsku sliku frazema. Drugim riječima, kontrastirani se frazemi podudaraju i na planu izraza i na planu sadržaja. Djelomično ekvivalentni frazemi semantički su podudarni te dijele istu pozadinsku sliku, ali među njima postoje razlike na leksičkom, morfološkom, sintaktičkom ili strukturnom planu. Značenje semantički podudarnih frazema iskazuje se različitim komponentama i motivirano je različitom slikovitošću, ali prijevodni ekvivalent nemaju u opisnim strukturama već u ciljnome jeziku imaju svoj frazeološki ekvivalent. Frazemi nulte ekvivalencije nemaju svoj ekvivalent u frazeološkom fondu kontrastiranoga jezika (Čagalj i Svitkova, 2014: 2-4).

\section{ANALIZA HINDSKIH FRAZEMA SA SASTAVNICOM ROṬĪ/ KRUH PREMA STUPNJU FRAZEOLOŠKE EKVIVALENCIJE}

\subsection{Potpuna ekvivalencija}

Analizom rječničke građe ustanovljeno je da samo jedan frazem ima svoj potpuni ekvivalent $\mathrm{u}$ hrvatskome jeziku, odnosno da s hrvatskim ekvivalentom dijeli isti leksički sastav, ista gramatička obilježja, istu pozadinsku sliku a time i isto značenje. Riječ je o frazemu roți kamāna 'zarađivati rot $\bar{\imath}^{\prime}$ ' koji odgovara hrvatskome frazemu zaradivati kruh (primjer 1.). Mrežnim je pretraživanjem zamijećeno da se pridjevna tvorbena inačica, rozi roṭi kamānna** 'zarađivati svagdašnju roțī', susreće češće. ${ }^{11}$ Hindski rječnici ne bilježe tu inačicu pa se ovdje iznosi kao zaseban frazem koji odgovara hrvatskome frazemu zaradivati svagdašnji kruh (primjer 2.).

\footnotetext{
${ }^{10}$ O tipologiji frazemske ekvivalencije v. i Vidović Bolt (2019: 348-350).

${ }^{11}$ https://wehindi.wordpress.com/author/wehindi/ (prosinac 2019.).
} 
(1) Śeher kī bhīr mẽ bhāgtā maĩ roțī kamāta hū. ${ }^{12}$

Zarađujem kruh jureći kroz gradsku vrevu.

(2) Sadguru batāte haĩ ki unhẽ kabhī rozī rotī kamāne kī apnì kābiliyat par sandeh nahĩ thā, aur unke pitā is se bahut khī thte the. ${ }^{13}$

Sadguru kaže da nikada nije sumnjao u svoju sposobnost zarađivanja svagdašnjega kruha i da je njegov otac zbog toga bio vrlo zabrinut.

\subsection{Djelomična ekvivalencija}

Roṭi ćalāna. Hindski frazem roți ćalāna djelomično se podudara s hrvatskim frazemom zarađivati kruh. Oba frazema sadrže prijelazni glagol i imenicu roțil/ kruh u akuzativu jednine, ${ }^{14}$ imaju isto značenje 'živjeti od svoga rada, zaraditi/ zarađivati za život, biti financijski samostalan', međutim djelomično se razlikuju na leksičkoj razini. U hindskome je primjeru prisutan glagol ćalāna 'pokrenuti, održavati u pokretu, voziti, koristiti, voditi' itd., a u hrvatskome glagol zarađivati.

(3) Ravi mazdūrī karke rotī ćalātā hai. ${ }^{15}$

Ravi zarađuje kruh fizičkim poslovima.

Rotiyā lagān $\bar{a}^{*}$ - doći do roți, steći roție. Značenje je frazema podudarno sa značenjem hrvatskoga frazema doći do 〈svoga〉 kruha 'početi zarađivati za život, osamostaliti se, postati financijski neovisan, stati na vlastite noge'. Frazemi se razlikuju na morfosintaktičkoj razini budući da hindski glagol lagānā otvara mjesto akuzativu (izraženom u nominativu), dok u hrvatskome jeziku prijedlog do zahtijeva genitiv. Također, imenica je roțī u množini, dok je $\mathrm{u}$ hrvatskome frazemu kruh $\mathrm{u}$ jednini.

Kahĩ rotiyã lagāo, nahĩ to yahã se bhāgnā paregā.

Dođi nekako do kruha inače ćeš morati pobjeći odavde.

Rotiyā lagnā. Glagol lagnā neprijelazna je inačica glagola lagānā.

(4) Đab merì naukrī laḡ̄ tab merī mã ne kahā merì rotiyā lag gaȳ̄ hai. ${ }^{16}$

Kad sam dobio posao, moja je majka rekla da sam došao do svoga kruha.

\footnotetext{
12 https://nojoto.com/post/71e7ba6418dc8a1fac0a2b06249e9c44 (prosinac 2019.).

${ }^{13}$ https://isha.sadhguru.org/in/hi/sadhguru/man/inventive (prosinac 2019.).

${ }^{14} \mathrm{U}$ hindskome je jeziku akuzativ izražen nominativom ako je riječ o neživome, neodređenom objektu.

15 http://hindigrammar.in/muhawara6.html (prosinac 2019.).

16 https://www.hindisamay.com/content.cspx (prosinac 2019.).
} 


\subsection{Samo semantička podudarnost}

U ovo su potpoglavlje uvršteni hindski frazemi od kojih se hrvatski frazemi razlikuju na planu izraza, odabirom leksema i pozadinskom slikom. Prema strožem kriteriju klasifikacije frazema prema stupnju ekvivalencije, niže bi navedeni frazemi bili navedeni kao frazemi nulte ekvivalencije. Ipak, budući da imaju isto značenje, odnosno da su semantički podudarni i da imaju svoj frazeološki ekvivalent $u$ hrvatskome jeziku, navedeni su u zasebnome potpoglavlju. Prvo su navedeni hindski i hrvatski frazemi koji se djelomično podudaraju uzme li se u obzir da frazemi oba jezika sadrže leksem roți, odnosno kruh, a potom hindski frazemi čiji hrvatski frazeološki ekvivalenti ne sadrže leksem kruh.

Do đū ki roți ${ }^{* *}$ - dosl. roțī od dva vremena ili dva dijela dana (obrok dva puta u danu). ${ }^{17}$ Značenje mu je 'ono najnužnije ili dovoljno za preživljavanje'. Hrvatski frazemi kojima je značenje otprilike isto jesu kora kruha, za koru (koricu) kruha kojim se neizravno opisuje „stanje siromaštva, ali i upućuje na težak život i rad čija je svrha zadovoljenje samo osnovnih životnih potreba" (Opašić, Čunović i Fumić 2014: 94).

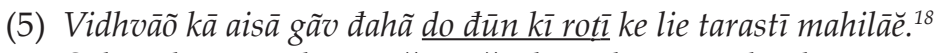
Selo udovica u kojem žene žude za koricom kruha.

Roțiyã torn $\bar{a}^{*}$ - dosl. lomiti/ kidati/ trgati roți. Značenje je frazema 'dobivati hranu bez rada, besposličariti, izbjegavati posao' pa odgovara hrvatskome frazemu kruh bez motike.

Vo mahīnõ se yahã roțiyã tor rahā hai, ākhir is mehengī mĕ kyā soćtā hai?

On već mjesecima jede kruh bez motike. Uostalom, što [si on] misli u ovo doba oskudice?

Treba, međutim napomenuti, da mrežnim pretraživanjem nije pronađen primjer uporabe toga frazema. Naprotiv, sintagma roțiyã tornnā koristi se $\mathrm{u}$ svome doslovnome značenju 'kidati/ lomiti roțī' na komadiće prije stavljanja u usta ili posluživanja na tanjuru.

Muft kī roțiyã torn $\bar{a}$ - lomiti besplatne roție. Ova se pridjevna inačica prethodnoga frazema susreće vrlo često. Ovisno o kontekstu, svoj frazeološki ekvivalent može imati ne samo u hrvatskome frazemu kruh bez motike (primjer 6.), već i u drugim frazemima kao što su biti (živjeti) na čijoj grbači, visjeti komu na vratu čije je značenje "financijski opteretiti koga, nametati se kao obveza, padati pod čiju skrb" (Opašić, Cunović, Fumić 2014: 96) (primjer 7.).

\footnotetext{
${ }_{17}$ https://www.hindikunj.com/2018/06/do-june-ki-roti.html (prosinac 2019.).

${ }^{18}$ https://www.khabrainabhitak.org/35560/ (prosinac 2019.).
} 
(6) Đelõ se śram huā gāyab, țhāle kaidı̄ "mehmān" ban tor rahe muft kī rotiyãa. ${ }^{19}$

U zatvorima više nema rada, besposleni su zatvorenici postali "gosti“ koji dobivaju kruh bez motike.

(7) Maĩne apne bețe se kahā ki tū pićhle 10 sāl muft kì rotiyã tor rahā hai. ${ }^{20}$

Rekao sam svom sinu: „Visiš mi na vratu proteklih deset godina.“

Roțī pānī ke cakkar mẽ hona $\bar{a}^{*}$ - dosl. biti u krugu roțī i vode. Značenje je frazema 'živjeti teško ili siromašno' pa značenjem odgovara hrvatskom frazemu živjeti na (o) kruhu $i$ vodi. Valja napomenuti da mrežnim pretraživanjem nije pronađen primjer za taj frazem, a primjer uporabe toga frazema ne daju ni korišteni rječnici.

Rozī roți ke cakkar mẽ hon $\bar{a}^{* *}$ - dosl. biti u krugu svagdašnje roțī. Inačica prethodnoga frazema, a koju hindski rječnici ne bilježe, značenjem i djelomičnom podudarnošću na leksičkom planu odgovara hrvatskom frazemu borba za nasušni (svagdašnji) kruh, potvrđenom u Frazeološkome rječniku hrvatskoga ili srpskoga jezika.

(8) Rozī roțì ke ćakkar me draivar ko gaìvānī paṛi apnī đān, hatyā ke virodh mẽ sarak đām. ${ }^{21}$

U borbi za svagdašnji kruh vozač izgubio život, u prosvjedu povodom [njegova] ubojstva zakrčena cesta.

Roțiyõ ke lāle parnna - teku sline za roțī. Svoj frazeološki ekvivalent ima u hrvatskome frazemu biti gladan čega, u ovome slučaju biti gladan kruha. Druga je mogućnost upotrijebiti hrvatski frazem teku (cure) komu sline 'osjećati neobičnu želju za čim/za kim' kako bi se zadržao hindski leksem lālā (slina), međutim hrvatski je frazem stilski obilježen pa je potrebno pažljivo promotriti kontekst u kojem je hindski frazem upotrijebljen (v. primjer 10.).

(9) Lekin zamìn ćalī đāne ke bād parivār ke sāmne rotiyõ ke lāle par đāẽge. ${ }^{22}$ Međutim, kad izgubi zemlju, obitelj će biti gladna kruha.

(10) Yahã subah se śām tak ke bīć bhāgya ne kitnõ ko dhanī se nirdhan aur nurdhan se bhikhārī banā diyā. Sabere do log mahal mẽ baithe the unhẽ is samay rotiyõ ke lāle pare haî. ${ }^{23}$

\footnotetext{
${ }_{19}$ patrika.com/udaipur-news/central-jail-udaipur-police-crime-in-udaipur-5309677/ (prosinac 2019.).

${ }^{20} \mathrm{https} / /$ liveindia.live/farah-khan-said-to-his-10-son-you-have-been-breaking-free-bread-for-thelast-10-years/ (prosinac 2019).

${ }^{21}$ https://m.dailyhunt.in/news/india/hindi/bihar+headlines-epaper-biharhea/roji+roti+ke+chakkar+me+draivar+ko+gavani+padi+apani+jan+hatya+ke+virodh+me+sadak+jam-newsid-89011065 (prosinac 2019.).

${ }^{22}$ https://www.amarujala.com/uttar-pradesh/etah/womans-protest-in-etah-bjp-leader-etah-newsagr404512253 (prosinac 2019).

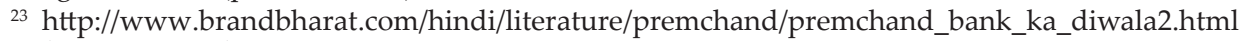
(prosinac 2019).
} 
Kolike li je ovdje sudbina od jutra do večeri od bogataša pretvorila u siromahe, a od siromaha u prosjake. Onima koji su jutros sjedili u palači sada teku sline za kruhom.

Roțī ko tarasnā - žudjeti, žeđati (za) roțî. Značenje je frazema 'biti gladan, siromašan, nemati ni najnužnije'. Frazem se može prevesti hrvatskim frazemom biti gladan (kruha).

(11) Pakistān mĕ rotī ko taras rahe haĩ log, 70 rūpae huī àte kī kīmat. ${ }^{24}$

U Pakistanu su ljudi gladni kruha, brašno doseglo cijenu od 70 rupija.

Ek tave $k \bar{i}$ roțī, kyā choți $k y \bar{a}$ moț $\bar{\imath}^{* *}$ - dosl. roțī od (s) iste tave, bila debela ili tanka. ${ }^{25}$ Hindskim se frazemom sugerira bliskost među pojedincima, njihov sličan ili isti karakter, te nepostojanje sukoba ili razmirica među njima. Značenjem odgovara hrvatskim frazemima biti kao prst i nokat, biti s kim kao nokat i meso.

(12) Abhī to ek tave kī rotī, kyā ćhotī kyā motī kā bhāv hai. Aććhā hai. Lekin bāl baćće hõge. ${ }^{26}$

Sad smo kao prst i nokat. Dobro je. Ali doći će djeca.

Dānt kāṭi roți khān $\bar{a}^{*}$-dosl. jesti roți kojega grize (jedan zub). Frazemom se opisuje prijateljski ili skladan odnos ili, drugim riječima, nepostojanje razilaženja u mišljenju, razmirica i sukoba među pojedincima. Prikladan bi hrvatski frazeološki ekvivalent bio slagati se kao braća. Iako je utemeljen na slici dijeljenja kao znaka zajedništva, frazem jesti (lomiti) s kim pogaču nije odgovarajući ekvivalent budući da mu je značenje 'živjeti s kim' (Hrnjak, 2007: 199). ${ }^{27}$ Hindski frazem ne podrazumijeva suživot.

Ve donõ to dānt kâtī rotī khāte haĩ.

Njih se dvojica pak slažu kao braća.

Roțī par roțī rakhkar khāna $\bar{a}^{*}$ - dosl. jesti stavivši/ položivši roțī na roți U frazemskoj je pozadinskoj slici obilje kruha, bogatstvo ili luksuz koji si netko može priuštiti pa značenjski odgovara hrvatskim frazemima živjeti $u$ svili i kadifi, živjeti na (velikoj) visokoj nozi, plivati (živjeti) u slasti i lasti (masti), živjeti kao bubreg u loju, živjeti kao beg.

Uskā kyā pūćhnā hai? Vo to àjkal rotī par rotī rakhkar khā rahā hai.

Što on ima tražiti? Pa on sada živi kao bubreg u loju.

\footnotetext{
${ }^{24}$ https://m.dailyhunt.in/news/india/hindi/news+remind+video-epaper-nwsrvid/omg+pakistan+me+roti+ke+lie+taras+rahe+hai+log+70+rupae+kilo+hui+aate+ki+kimat+news+remind-newsid-133851048 (prosinac 2019.).

25 https://bharatdiscovery.org/ (prosinac 2019.).

${ }^{26}$ http://bindashbol.com/Home/NewsDetail/747-ranchi (prosinac 2019.).

27 „Kad se u frazemu pojavljuje samostalno, leksem pogača preuzima simboliku kruha kao suštinske hrane, pa je ponekad kao varijanta i zamjenjiv leksemom kruh" (Hrnjak, 2007: 199).
} 
Roṭi $k \bar{\imath} k h \bar{a} k \boldsymbol{k} h \bar{a} r n \bar{a}^{*}$ - dosl. raspršivati prašinu (mrvice) od roțī. Značenje mu je 'laskati, podvlađivati, ulizivati se'. Neki od hrvatskih frazema koji dijele isto značenju jesu ići niz dlaku komu, uvlačiti se (zavlačiti se) pod rep komu, kaditi komu tamjanom.

Merā kām ho yā na ho, maĩ kisī kī rootī kī khäk jhar nahĩ saktā.

Imao posao ili ne, ja se nikomu ne mogu zavlačiti pod rep.

Dāl roṭī se khuś-sretan/ zadovoljan s dālom i roțī. Značenje je frazema ‘biti zadovoljan s malim ili najnužnijim'. Po značenju hindski frazem odgovara hrvatskome frazemu ne tražiti kruha preko pogače.

Jamājathā to nahĩ hai, par dāl roțī se khuś haĩ.

Nagomilanoga bogatstva nemamo ali ne tražimo kruha preko pogače.

Ipak, pri prevođenju frazema često nije dovoljno naći (približan) ekvivalent već je nužno pažljivo promotriti kontekst u kojem se frazem pojavio i potom odlučiti koja je od prijevodnih strategija najprimjerenija za njegovo prevođenje. Kao ilustracija te tvrdnje može poslužiti sljedeći primjer.

(13) Saț̣ā vāle, kamoditī eksćeña ke mārket ke log bhī hairān haĩ ki dāl rotī se khuś rehne vāle logõ ke deś mẽ itnì biryānī kī khapat baṛh rahī hai. ${ }^{28}$

Čak se i ljudi koji se bave trgovinom i razmjenom dobara na tržištu čude da je u državi u kojoj su ljudi zadovoljni dālom i roțī u tolikoj mjeri porasla potražnja za biryāni ${ }^{29}$.

Prevede li se gore dani primjer tako da se uklopi hrvatski frazem ne tražiti kruha preko pogače (Čak se i ljudi koji se bave trgovinom i razmjenom dobara na tržištu čude da je u državi u kojoj ljudi ne traže kruha preko pogače toliko porasla potražnja za biryāni), izgubit će se igra riječi prisutna u izvorniku. Naime, dāl i roțī se zbog svoje niske cijene i dostupnosti smatraju sirotinjskim ili priprostim jelima dok je biryāni jelo koje si, u pravilu, ne mogu priuštiti ljudi plitkoga džepa ili oni koji jedva krpaju kraj s krajem. Dani je primjer tako ilustracija još jedne od poteškoća koje se susreću pri prevođenju frazema budući da, u određenome kontekstu, frazemi uz preneseno mogu zadržati i svoje doslovno značenje (usp. Forko, 2009: 98).

\subsection{Nulta ekvivalencija}

U ovome su poglavlju svoje mjesto našli hindski frazemi za koje nije pronađen odgovarajući frazeološki ekvivalent u hrvatskome jeziku. Frazemi, kao odraz pojedine kulture, nerijetko nemaju svoj ekvivalent u drugome jeziku što može dovesti do poteškoća u njihovu prevođenju. Kako ističe Forko, prevođenje frazema i poslovica pripada sadržajnom prevođenju, odnosno

\footnotetext{
${ }^{28} \mathrm{https} / /$ m.dailyhunt.in/news/india/hindi/avn+post-epaper-avnpost/vyangy+dal+dal+ki+dal-newsid-150009360 (prosinac 2019.).

${ }^{29}$ Biryān̄, jelo od mesa i riže. Poslužuju se, također, i „vegetarijanske inačice“ biryānī.
} 
pri prevođenju se frazema treba ponajprije usredotočiti na značenje frazema (Forko, 2009: 97).

Roṭī pānn̄ mẽ lagn $\bar{a}^{*}$ - zaokupiti se roțī i vodom. Značenje je frazema 'započeti bračni život i preuzeti odgovornost za obitelj', odnosno ostaviti razonodu i mladenački život i posvetiti se prehranjivanju obitelji. Budući da za frazem mrežnim pretraživanjem nije pronađen primjer, može se zaključiti da je izašao iz uporabe, a takav je zaključak potkrijepljen i nepostojanjem primjera u korištenim rječnicima te usmenom komunikacijom sa sveučilišnom nastavnicom Jyoti Śarmom. Frazem, koliko mi je poznato, nema svoj frazeološki ekvivalent $u$ hrvatskome jeziku.

Dānt kățī roṭ̂ hon $\bar{a}$ - dosl. roți kojega grize (jedan) zub. Frazemom se opisuje čvrsta, neraskidiva veza ili odnos.

(14) Par ćunāv ke bād sarkār banāne ke lie ve aise ekđut ho gaye đaise ki donõ mẽ hameśá se dānt kātī rotī rahī hai . ${ }^{30}$

Međutim, nakon izbora, za sastavljanje su se vlade tako ujedinili kao da je međunjima oduvijek postojalo čvrsto prijateljstvo.

Roṭi bețī hon $\bar{a}$ - dosl. biti roțī (i) kćer. Frazem ima slično značenje kao i ranije naveden frazem dānt kāțī roți honā. Ipak, ovim se frazemom dodatno impliciraju ženidbene ili pak trgovinske ili političke veze među pojedincima ili stranama.

(15) Bhārat ka parosī deś Nepāl se rotī betī kā riśtā rahā hai. Donõ deś ek dūsre ke sahyogī rahe haĩ. ${ }^{31}$

Indija njeguje prijateljski odnos sa susjednom državom Nepalom. Obje si države međusobno pomažu.

$\operatorname{Roṭī} p \bar{a} n \vec{n}^{* *}$ - roți (i) voda. ${ }^{32}$ Kruh i voda su temeljne čovjekove namirnice, odnosno uvjet njegova preživljavanja, međutim hrvatski frazemi u kojima se susreću oba leksema kao što su živjeti na (o) kruhu i vodi i staviti koga na kruh i vodu imaju uvijek negativno značenje i upućuju na (krajnje) siromaštvo, odnosno čovjek nema ništa drugo osim kruha i vode što znači da je na rubu egzistencije (Opašić, Čunović i Fumić, 2014: 93). Primjeri pronađeni mrežnim pretraživanjem svjedoče da imati roți i vodu znači imati malo, ali dovoljno za život, pa značenje frazema nije negativno.

(16) Uske vivāh ne unhẽ sab se zyādā ćintāmukt kar diyā thā. "Ćalo. Kam se kam

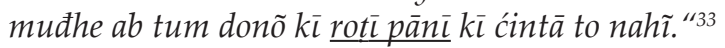

Njezina ju je udaja ponajviše oslobodila briga. „Idi. Ako ništa drugo, sada se barem ne brinem imate li vas dvoje dovoljno za život."

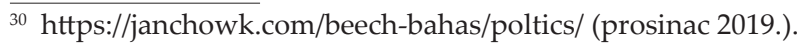

$31 \mathrm{https} / / /$ livecities.in/trending/indo-nepal-relationship-present-situation/ (prosinac 2019.).

32 https://bharatdiscovery.org/ (prosinac 2019.).

33 Gupta, P. (2016) Burī Laṛkì. Hind Yugm, str. 50.
} 
Dāl roṭi ćalnā - dosl. idu/ kreću se dāl ${ }^{34}$ i roțī. Značenje je hindskoga frazema 'imati dovoljno za preživljavanje ili za život'.

(17) Uskī āmdanī kam hai, phir bhi dāl rotī ćal đātū haí. ${ }^{35}$

Prihodi su mu mali. Ipak, ima dovoljno za preživljavanje.

\section{ZAKLJUČAK}

Cilj je ovoga rada bio ponuditi prijevodne ekvivalente hindskih frazema sa sastavnicom roți. Iznesena su ukupno dvadeset i dva hindska frazema od kojih je sedamnaest izlučeno iz hindskih frazeoloških rječnika. Među njima je sedam frazema za koje mrežnim pretraživanjem nije pronađen primjer uporabe što upućuje na zaključak da su ti frazemi prešli u pasivni fond jezika. Pet je hindskih frazema pronađeno mrežnim pretraživanjem i dodatno potvrđeno usmenom komunikacijom s izvornim govornikom hindskoga jezika.

Prema stupnju frazeološke ekvivalencije, hindski su frazemi podijeljeni $\mathrm{u}$ četiri skupine. U skupinu potpune ekvivalencije uvrštena su dva hindska frazema koji se s hrvatskim ekvivalentima podudaraju u izrazu, leksičkome sastavu, pozadinskoj slici i time $u$ značenju. U skupinu djelomične ekvivalencije uvrštena su tri hindska frazema. Dvanaest hindskih frazema koji imaju svoj frazeološki ekvivalent u hrvatskome jeziku, iako se razlikuju na planu izraza, leksičkim sastavom i pozadinskom slikom, uvršteno je u skupinu koju tvore samo semantički podudarni frazemi. Posljednju skupinu čini pet hindskih frazema za koje $\mathrm{u}$ hrvatskome jeziku nije pronađen odgovarajući frazeološki ekvivalent. Najbrojniju skupinu čine hindski frazemi uvršteni u treću skupinu (semantička podudarnost).

Navedena značenja hindskih frazema pokazuju da je roți, kao što je slučaj s kruhom u hrvatskoj frazeologiji, shvaćena kao uvjet za život ili preživljavanje. Poistovjećuje se s radom i zarađivanjem za život te obiljem. Postoje i primjeri negativno obilježenih frazema u kojima nemogućnost da se dođe do roți sugerira siromaštvo, glad i bijedu. Također, kao i u hrvatskome jeziku, pojedini frazemi sa sastavnicom roți upućuju na bliskost ili vezu među pojedincima. Iako hindski i hrvatski frazemi odražavaju dva geografski i kulturno udaljena i tipološki različita jezika, relativno se mali broj frazema nulte ekvivalencije može objasniti činjenicom da simbolika roți odgovara simbolici kruha, odnosno da su frazemi oba jezika sa sastavnicom roți, odnosno kruh, motivirani usporedivom pozadinskom slikom. Kroz pojedine se primjere nastojalo ukazati i na poteškoće koje se mogu javiti prilikom prevođenja hindskih frazema.

\footnotetext{
34 Leća, biljka iz porodice mahunarki.

35 Jagannath, V. R. (2016) Saral Hindi Kosh. New Delhi: New Saraswati, str. 113.
} 


\section{LITERATURA}

Baker, M. (1992) In Other Words - A Coursebook on Translation. London: Routledge.

Baza frazema hrvatskoga jezika. http://frazemi.ihjj.hr/ (prosinac 2019.).

Čagalj, I. i Svítková, M. (2014) Tipologija frazeološke ekvivalencije na primjeru hrvatskih i slovačkih frazema s ihtionimskom sastavnicom. U Vidović Bolt, I. (ur.) Životinje u frazeološkom ruhu. Zagreb: FF-press, 1-15.

Fink-Arsovski, Ž. (2002) Poredbena frazeologija: pogled izvana i iznutra. Zagreb: FF Press.

Fisiak, J. (1980) Editor's Introduction. U Fisiak, J. (ur.) Theoretical Issues in Contrastive Linguistics. Amsterdam: John Benjamins B.V. (1-7).

Forko, J. (2009) Prevođenje frazema - Sizifov posao. Hrvatistika 3 (3), 93-98.

Gupta, P. (2016) Burī Larkī. Hind Yugm.

Hrnjak, A. (2007) Kulinarski elementi u hrvatskoj i ruskoj frazeologiji. Rasprave Instituta za hrvatski jezik i jezikoslovlje 33 (1), 197-216.

Hudeček, L. i Mihaljević, M. (2009) Jezik medija - publicistički funkcionalni stil. Zagreb: Hrvatska sveučilišna naklada.

Jagannath, V. R. (2016) Saral Hindi Kosh. New Delhi: New Saraswati.

Kolokacijska baza hrvatskoga jezika. http://ihjj.hr/kolokacijel (prosinac 2019.).

Kovačević, B. (2012) Hrvatski frazemi od glave o pete. Zagreb: Institut za hrvatski jezik i jezikoslovlje.

Lado, R. (1957) Linguistics Across Cultures. Applied Linguistics for Language Teachers. Ann Arbor: The University of Michigan Press.

Matešić, J. (1982) Frazeološki rječnik hrvatskoga ili srpskoga jezika. Zagreb: Školska knjiga.

McGregor, R. S. (ur.) (1997) The Oxford Hindi-English Dictionary. Delhi: Oxford University Press.

Menac, A. (1970) O strukturi frazeologizama. Jezik 18 (1), 1-4.

Menac, A. (1994) Frazeologija u različitim tipovima jednojezičnih rječnika. Filologija 22-23, 161-168.

Menac, A., Fink-Arsovski, Ž. i Venturin, R. (2003) Hrvatski frazeološki rječnik. Zagreb: Naklada Ljevak.

Mihaljević, M. i Kovačević, B. (2006) Frazemi kroz funkcionalne stilove. Časopis za kulturu hrvatskoga knjižeonog jezika 1, 1-40.

Opašić, M., Čunović, N. i Fumić, M. (2014) Bogatstvo i siromaštvo u hrvatskoj frazeologiji. Fluminensia 26 (2), 91-103.

Pavlović, N. (2015) Uvod u teorije prevođenja. Zagreb: Leykam international d.o.o.

Sarhindī, R. J. (1940) Hindı̄ Muhāvarā Koś. Ilāhābād: Rāmnārāyaṇ Lāl.

Tivārī, B. (1991) Hindī Muhāvarā Koś. Delhi: Hindī Buk Sențar.

Turk, M. i Opašić, M. (2008) Supostavna raščlamba frazema. Fluminensia 20 (1), 19-31.

Verma, S. K. i Sahai, R. N. (ur.) (2003) The Oxford English-Hindi Dictionary. Delhi: Oxford University Press.

Vidović Bolt, I. (2019) Frazemi - prevoditeljski kamen spoticanja. U Macan, Ž. (ur.) Slavofraz 2018 Frazeologija, učenje i poučavanje. Rijeka: Sveučilište u Rijeci, Filozofski fakultet, 345-360. 


\section{HINDĪ PHRASEMES WITH COMPONENT ROṬĪ/ BREAD AND THEIR TRANSLATION INTO CROATIAN LANGUAGE}

The aim of the paper was to present Hindī phrasemes containing the lexeme roți (bread) and to offer their translation into the Croatian language. Twenty-two Hindī phrasemes were listed together with their meaning. Hindi phrasemes were divided, according to the level of equivalency, into four groups: direct, partial, semantical and zero equivalency. Out of twenty-two Hindī phrasemes only two had their direct equivalents in the Croatian language. Three of them showed partial equivalency, and twelve only semantical equivalency with the Croatian phrasemes. For five Hindī phrasemes no phraseological counterparts were found in the Croatian language. In the absence of the Indian national corpora, variant phrasemes were listed as separate phrasemes. The examples of the use of Hindi phrasemes were also provided and taken mostly from online sources. Some of the given examples illustrate the difficulties that might occur while translating phrasemes belonging to a distant and different cultural background.

Keywords: Hindi Language, Croatian language, phraseme, phraseological equivalency, roți, bread. 